\title{
Humoral response of the mouse to Treponema pallidum
}

\author{
JAMES M SAUNDERS AND JAMES D FOLDS \\ From the Department of Microbiology and Immunology, School of Medicine, University of North \\ Carolina, Chapel Hill, North Carolina, USA
}

SUMMARY To investigate the development of the humoral immune response of mice to infection with Treponema pallidum, Balb/c and C57Bl mice were injected intradermally with $10 \times 10^{6}$ virulent organisms. Serum samples were taken from the mice at weekly intervals after infection and used in the electrophoretic transblotting technique to detect $T$ pallidum and $T$ phagedenis biotype Reiter antigens. The serum samples taken from infected mice at 21, 42, 84, and 126 days after infection recognised two to $15 \mathrm{~T}$ pallidum antigens, with a gradual but continual increase in the number of antigens recognised. The same antisera to $T$ pallidum recognised five cross reactive $T$ phagedenis biotype Reiter antigens. Mice injected with $10 \times 10^{6}$ heat killed $T$ pallidum organisms failed to recognise $T$ pallidum antigens, as shown by the blotting technique. When mice infected with $T$ pallidum were given antibiotics, the development of the humoral response was interrupted. These experiments indicated that mice respond more slowly than rabbits to $T$ pallidum, which may be because $T$ pallidum is weakly immunogenic in mice.

\section{Introduction}

Treponema pallidum, the aetiological agent of syphilis, continues to be an important public health problem in the United States.' Infection with $T$ pallidum in man and experimental rabbits typically leads to the development of a characteristic lesion. During infection the host mounts a complex immune response to $T$ pallidum, which probably resolves the lesion. ${ }^{23} \mathrm{~A}$ characteristic feature of syphilis, however, is the development of latent stages, which may be due to the persistence of $T$ pallidum in some people. ${ }^{23} \mathrm{~A}$ major obstacle to elucidating the role of humoral and cell mediated immunity in syphilis has been the lack of a suitable inbred animal model. The most widely used animal model for experimental infection with $T$ pallidum continues to be the rabbit. Although inbred strains of rabbits exist, they are expensive and not readily available. The inbred mouse offers investigators a well defined genetic and immunological background for the study of many infectious diseases. We have previously reported that certain strains of inbred mice infected with $T$

Address for reprints: Professor James D Folds, Department of Microbiology and Immunology, University of North Carolina, Chapel Hill, North Carolina 27514, USA

Accepted for publication 13 December 1984 pallidum do not develop a characteristic lesion, although the organism appears to persist within mouse tissue for several months after infection. ${ }^{45}$ In addition, inbred mice injected with virulent $T$ pallidum develop an appreciable humoral immune response as shown by the enzyme linked immunosorbent assay (ELISA) and the microhaemagglutination (MHA-TP) assay. ${ }^{4}$ We were interested in investigating further the development of the humoral immune response in mice experimentally infected with $T$ pallidum to assess which $T$ pallidum antigens are recognised by serum from these mice and compare them with the antigens recognised by serum from rabbits and man infected with $T$ pallidum. We also investigated the effect of antibiotic treatment on the antibody response of mice infected with $T$ pallidum.

\section{Materials and methods}

\section{ANIMALS}

Adult male Balb/c mice were bought from Jackson Laboratories Bar Harbor, Maine, USA; the C57/BL mice were obtained from $\mathrm{Dr} G$ Haughton, Department of Microbiology and Immunology, of this university; and the rabbits were obtained from Dutchland, Denver, Pennsylvania, USA. All animals were maintained at $18^{\circ} \mathrm{C}$ and fed antibiotic free food 
in the animal facilities at the University of North Carolina.

SOURCE OF T PALLIDUM

$T$ pallidum, Nichols strain, was originally obtained from Dr Joel B Baseman. It was grown in cortisone treated rabbits by intratesticular inoculation as described previously. ${ }^{6}$ At peak orchitis (10-12 days after infection) the rabbit testes were excised and the $T$ pallidum organisms were extracted in $0.1 \mathrm{~mol} / 1$ phosphate buffered saline (PBS), pH $7 \cdot 2$, plus $5 \%$ heat inactivated normal rabbit serum. The extraction medium was centrifuged twice at low speed to remove contaminating host cells. At this stage the $T$ pallidum organisms were used to infect mice. $T$ pallidum organisms which were to be used as antigen for sodium dodecyl sulphate polyacrylamide gel electrophoresis (SDS-PAGE) and western blotting were then layered on to $42 \%$ Percoll solution (Sigma Chemical Co, St Louis, Missouri, USA) and centrifuged in a Sorvall SS-34 rotor at $32000 \times g$ for 30 minutes at $4^{\circ} \mathrm{C}$ to purify the organisms. The $T$ pallidum band was collected and centrifuged at $100000 \times g$ for 60 minutes at $4^{\circ} \mathrm{C}$ to pellet the Percoll. ${ }^{7}$ The $T$ pallidum was collected and centrifuged in an Airfuge (Beckman Co, Fullerton, California, USA) for five minutes to remove the remaining Percoll, which might otherwise have interfered with solubilising the $T$ pallidum for SDSPAGE.

GROWTH OF TREPONEMA PHAGEDENIS

BIOTYPE REITER

$T$ phagedenis biotype Reiter was originally obtained from Dr Joel B Baseman, The organisms were grown in spirolate broth (BBL, Cockeysville, Maryland, USA) supplemented with $10 \%$ heat inactivated normal rabbit serum. ${ }^{8}$ The cultures were inoculated with a $10 \%$ (volume per volume) seed culture and incubated for four to six days at $37^{\circ} \mathrm{C}$. The spirochaetes were harvested by centrifugation at $10000 \times g$ for 30 minutes at $4^{\circ} \mathrm{C}$ and washed four times in PBS. The $T$ phagedenis biotype Reiter was examined by dark field microscopy to count cell numbers, and aliquots were frozen.

\section{EXPERIMENTAL INFECTION}

With the exception of one group, Balb/c and C57/BL mice were inoculated intradermally with $10 \times 10^{6}$ freshly extracted virulent $T$ pallidum. Rabbits served as controls for the infectivity of the $T$ pallidum inoculum. They were injected with the same $T$ pallidum inoculum as the experimental mice, and in each case the rabbits developed orchitis 10 to 12 days after infection. The mice were divided into several groups. Those in group 1 received no further treatment. Those in group 2 were inoculated with heat inactivated (at $56^{\circ} \mathrm{C}$ for four hours) $T$ pallidum. Mice in group 3 and 4 received antibiotics from day two to day 42 after inoculation; those in group 3 received penicillin intramuscularly (2500 units every four days), and those in group 4 received tetracycline orally $(500 \mathrm{mg} / \mathrm{l}$ water). Mice in group 5 and 6 received antibiotics from day 42 to day 84 after infection; those in group 5 received penicillin intramuscularly (2500 units every four days), those in group 6 received tetracycline orally $(500 \mathrm{mg} / \mathrm{l}$ water). The antibiotic concentrations chosen were based on information from the CRC Handbook. ${ }^{9}$ The mice were bled before inoculation with $T$ pallidum and at weekly intervals after inoculation. The mouse serum was kept frozen at $-70^{\circ} \mathrm{C}$ until used.

\section{GEL ELECTROPHORESIS}

SDS-PAGE was undertaken with an 8-20\% gradient slab gel and the Laemmli discontinuous buffer system. ${ }^{10}$ Electrophoresis was performed at $5 \mathrm{MA}$ overnight and continued until one hour after the dye front was electrophoresed off the gel. The antigens of $T$ pallidum and $T$ phagedenis biotype Reiter $\left(4 \times 10^{9}\right.$ organisms $\left./ \mathrm{ml}\right)$ and marker proteins were dissolved in an equal volume of final sample buffer $(0.625 \mathrm{~mol} / 1$ trometamol (TRIS), $\mathrm{pH} 6.8,2 \%$ sodium dodecyl sulphate (SDS), and $5 \%$ 2-mercaptoethanol) for five minutes at $100^{\circ} \mathrm{C}$. The gels were stained with Coomassie blue to detect the polypeptides.

\section{WESTERN BLOTTING TECHNIQUE}

The western blotting technique was used to identify which antigens were recognised by serum from mice infected with $T$ pallidum. ${ }^{11}$ The treponemal proteins were separated by gel electrophoresis and transferred electrophoretically from the gel to a $0.20 \mu \mathrm{m}$ pore size nitrocellulose sheet (Sartorius Filters, Inc, Hayward, California, USA) at $195 \mathrm{MA}$ for one hour and $50 \mathrm{MA}$ for a further hour in $25 \mathrm{~mol} / \mathrm{l}$ TRIS, $192 \mathrm{mmol} / 1$ glycine, and $20 \%$ methanol. ${ }^{12}$ The transblots were stained with Amido black to ensure that the full range of molecular weights of proteins was transferred. The nitrocellulose sheets were incubated in 5\% OA-TSA (ovalbumin-TRIS saline azide buffer) for one hour to block the remaining protein binding sites. The nitrocellulose sheets were incubated overnight with mouse serum diluted $1 / 100$ in OA-TSA. The blots were washed for one hour with four changes of TSA and then incubated with $I^{125}$ Staph Protein A $\left(2 \times 10^{6}\right.$ counts per minute (cpm)) for two hours. The nitrocellulose sheets were washed extensively in TSA to remove unbound label, air dried, and autoradiographed. All stages of incubation and washing were carried out at room temperature. 


\section{Results}

POLYPEPTIDE PROFILES OF T PALLIDUM

(NICHOLS) AND T PHAGEDENIS BIOTYPE REITER $T$ pallidum, $T$ phagedenis biotype Reiter, and normal testicular extract, as well as molecular weight markers, were subjected to SDS-PAGE analysis. Figure 1 shows the complex polypeptide gel profile that can be identified after staining with Coomassie blue dye. $T$ pallidum and $T$ phagedenis biotype Reiter each contain at least 32 distinct proteins with molecular weights ranging from about 12000 to $>100000$ daltons. The normal testicular extract presents a less complex gel profile, with about 16 protein bands.

\begin{tabular}{llll}
1 & 3 & 4 & 5 \\
\hline & 3 & \\
0
\end{tabular}

FIG 1 Sodium dodecyl sulphate-polyacrylamide gel electrophoresis (SDS-PAGE) of Treponema pallidum, $T$ phagedenis biotype Reiter, and normal rabbit testicular extract. Lanes 1 and 5 contained molecular weight marker proteins, lane 2 contained T pallidum, lane 3 contained $T$ phagedenis biotype Reiter, and lane 4 contained normal testicular extract.

$T$ PALLIDUM (NICHOLS) AND T PHAGEDENIS BIOTYPE REITER ANTIGENS RECOGNISED BY SERUM FROM MICE INFECTED WITH $T$ PALLIDUM

The antigenicity of $T$ pallidum and $T$ phagedenis biotype Reiter polypeptides that had been separated by SDS-PAGE was analysed by the western blotting technique. Serum samples from the mice were used to assess the development of the antibody response to $T$ pallidum during experimental infection and to examine which of these antigens were shared with $T$ phagedenis biotype Reiter. Serum samples taken at various times after infection from $\mathrm{Balb} / \mathrm{c}$ mice that had been inoculated with $T$ pallidum but not treated (group 1) showed a gradual but steady increase in the number of $T$ pallidum antigens identified (fig 2). At $21,42,84$, and 126 days after infection, serum from these mice recognised $2,5,10$, and $16 T$ pallidum antigens respectively. Serum samples from group 1 at 42,84 , and 126 days after infection also recognised 3 , 4, and $5 T$ phagedenis biotype Reiter antigens iespectively. Normal mouse serum at dilutions as low as 1/25 failed to identify any $T$ pallidum or $T$ phagedenis biotype Reiter antigens. Serum from mice inoculated with heat killed $T$ pallidum (group 2) failed to recognise $T$ pallidum antigen.

\section{$T$ PALLIDUM (NICHOLS) AND T PHAGEDENIS BIOTYPE REITER ANTIGENS RECOGNISED BY MOUSE, HUMAN, AND RABBIT SERUM}

We were also interested in assessing which Tpallidum antigens were identified by serum from rabbits infected intratesticularly with $T$ pallidum and serum from people with secondary syphilis in comparison with the antigenic profile established with serum from mice infected with $T$ pallidum. Figure 3 shows that serum samples from infected mice, rabbits, and people are able to recognise similar $T$ pallidum and $T$ phagedenis biotype Reiter antigens, although some differences are noticeable.

EFFECT OF ANTIBIOTICS ON DEVELOPMENT OF HUMORAL IMMUNE RESPONSE TO T PALLIDUM (NICHOLS)

Serum from mice in group 3 that received penicillin from day 2 after inoculation identified 1,8 , and $2 T$ pallidum antigens at 21,42 , and 84 days after infection (fig 4 ) and serum from mice in group 4 that received tetracycline from day 2 after infection recognised 1,2 , and $2 T$ pallidum antigens at 21,42 , and 84 days after infection (data not shown). Mice in groups 5 and 6 (receiving antibiotics from day 42 after infection) developed the antibody response to $T$ pallidum as expected during the first 42 days after infection (fig 5). The antibody response failed to continue to develop, however, and reactivity to additional antigens was not observed once antibiotics had been administered. At day 84 after infection serum from mice in group 5 was reactive with only two $T$ pallidum antigens and serum from mice in group 6 recognised five $T$ pallidum antigens (data not shown). Generally, serum from mice given the anti- 


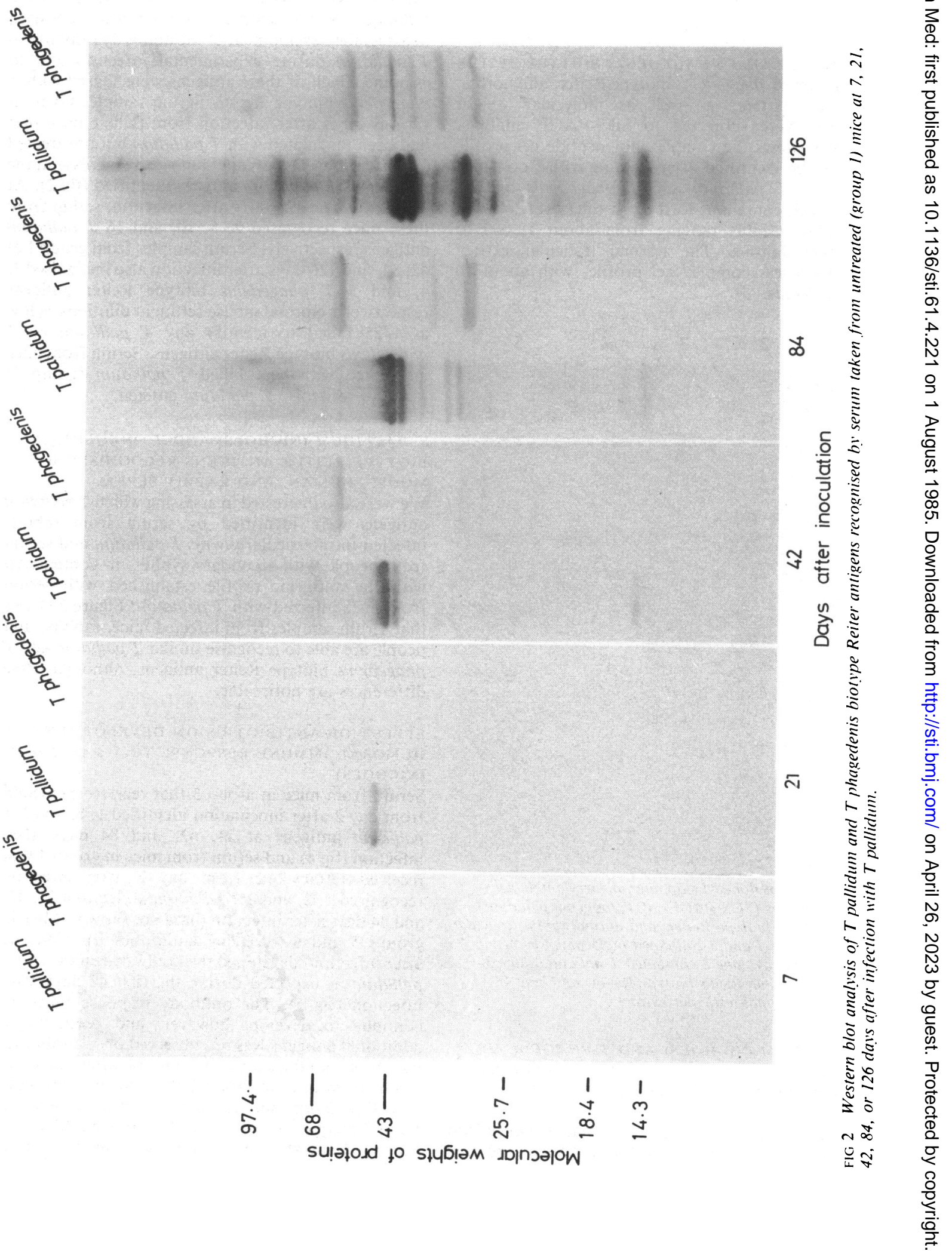




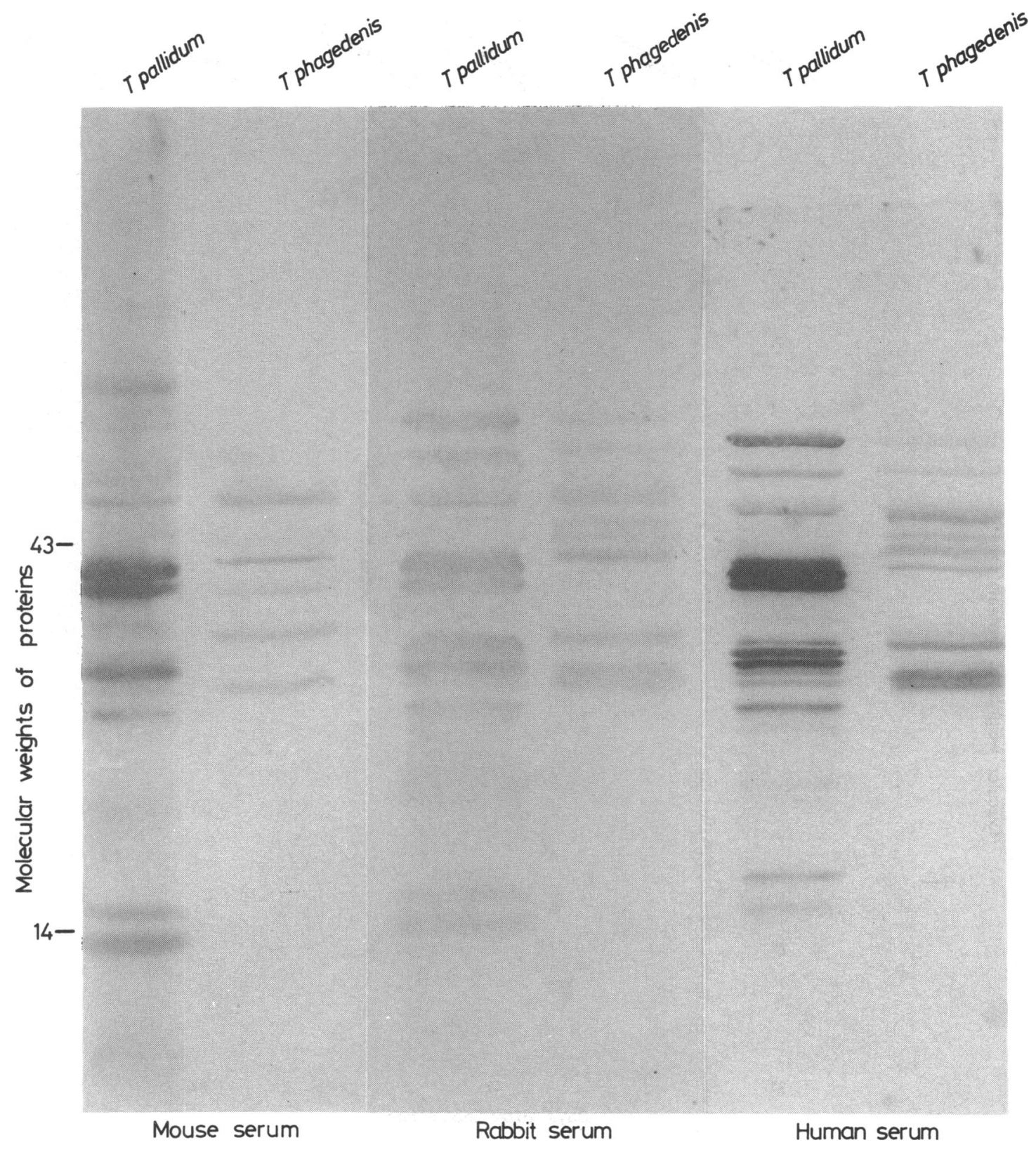

FIG 3 Western blot analysis of $T$ pallidum and $T$ phagedenis biotype Reiter antigens recognised by serum from mice infected 126 days earlier with $T$ pallidum, serum from a rabbit injected intratesticularly with $T$ pallidum, and serum from a patient with documented secondary syphilis. 


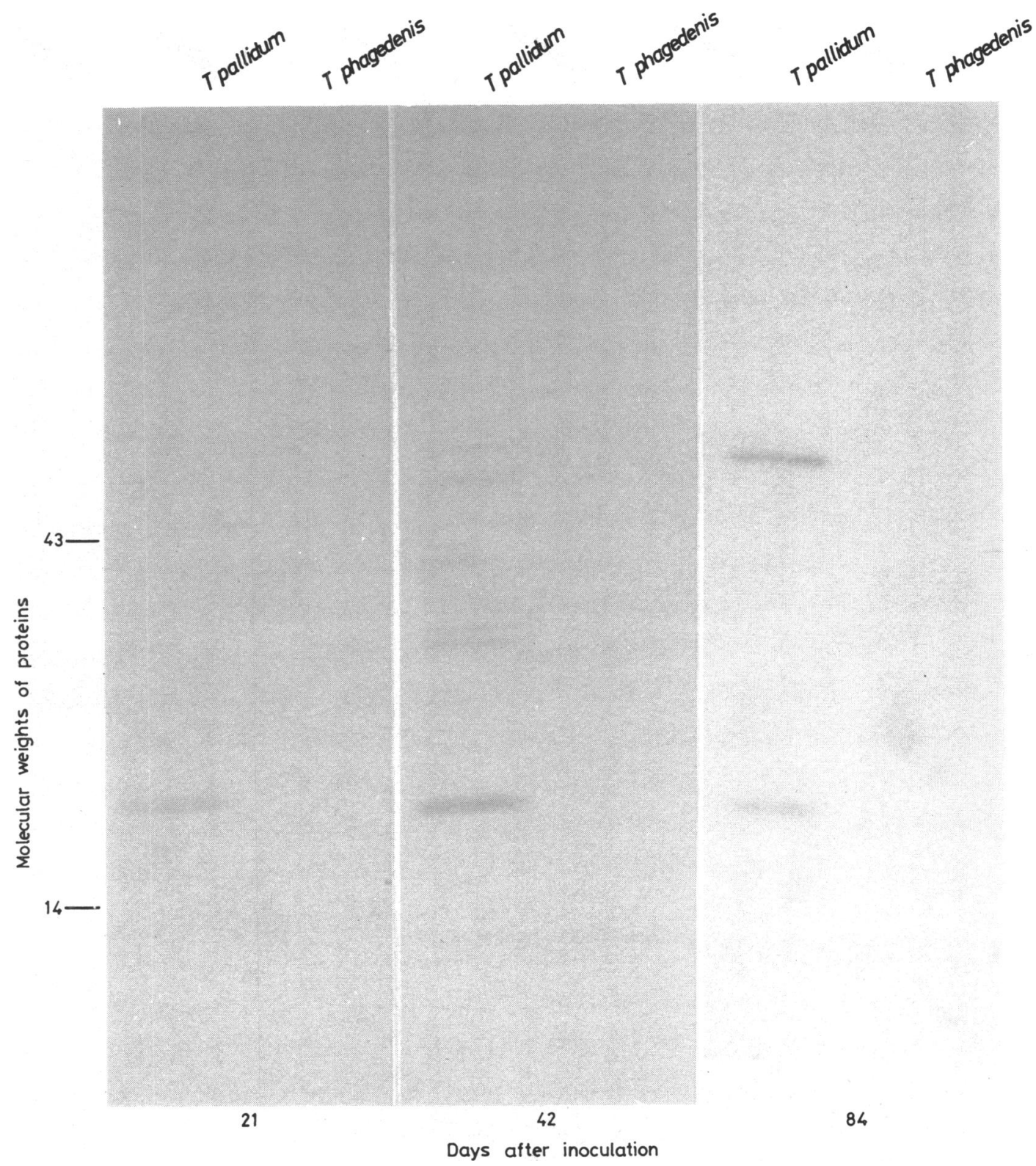

Hin 4 Western blot analysis of $T$ pallidum and $T$ phagedenis biotype Reiter antigens recognised by serum from mice treated with penicillin two davs after inoculation (group 3) taken at 2l,42, and 84 dav's after inoculation with treponemes. 


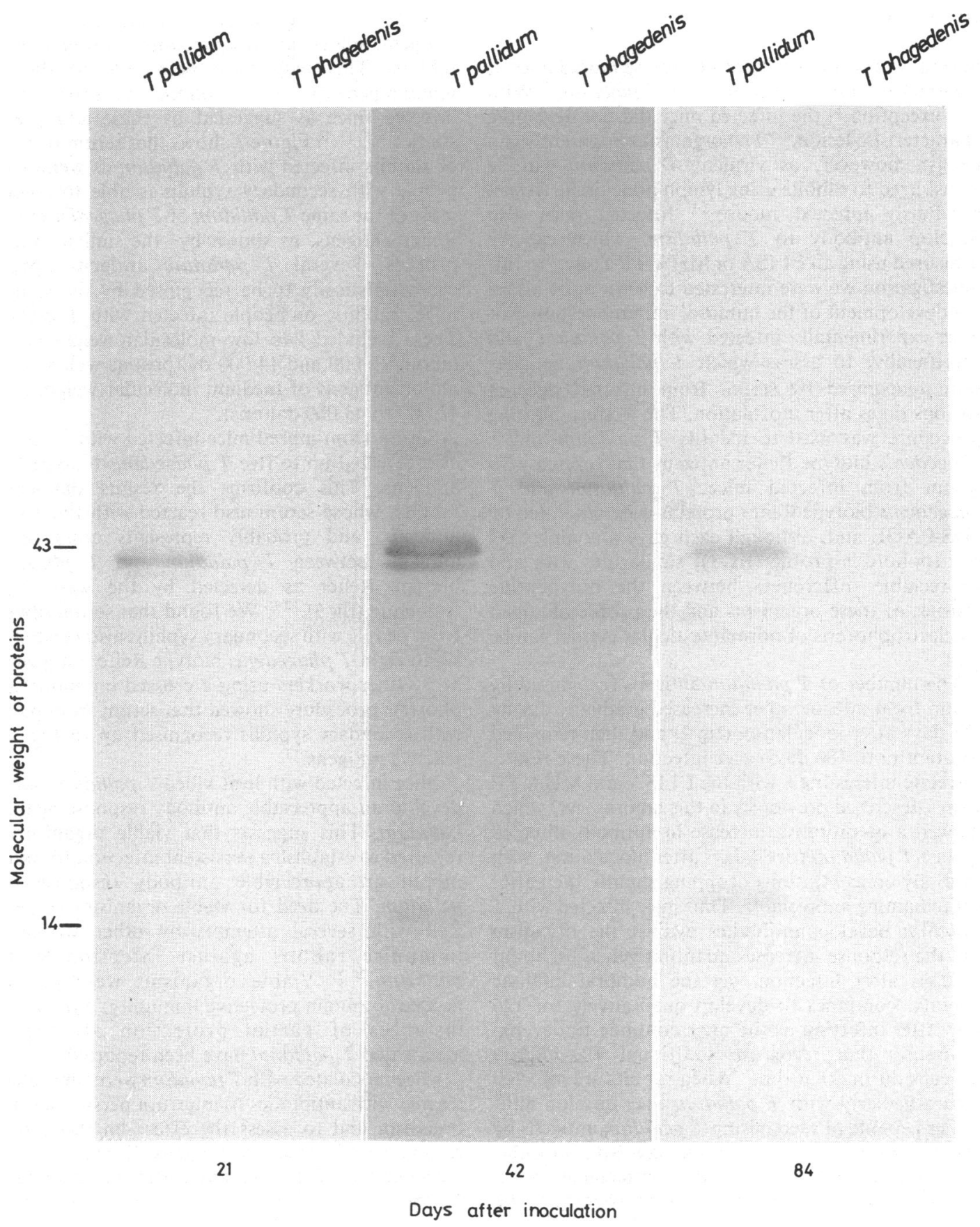

IIc 5 Western blot analysis of $T$ pallidum and $T$ phagedenis biotype Reiter antigens recognised by serum from mice treated with penicillin or tetracycline 42 days after inoculation (groups 5 and 6) taken at 21, 42, and 84 da1!s after inoculation with treponemes. 
biotics (groups 3, 4, 5, and 6) did not recognise the cross reactive $T$ phagedenis biotype Reiter antigens.

\section{Discussion}

Several workers have attempted to use inbred mice as a model to study infection with $T$ pallidum. ${ }^{5}$ With one exception, ${ }^{13}$ the infected mice did not develop a characteristic lesion. ${ }^{45}$ The organisms apparently can persist, however, as virulent $T$ pallidum can be transferred to rabbits using lymph node tissue from a previously infected mouse. ${ }^{23}$ Infected mice also develop antibody to $T$ pallidum, which can be measured using an ELISA or MHA-TP assay. ${ }^{4}$ In this investigation we were interested to learn more about the development of the humoral immune response of mice experimentally infected with $T$ pallidum, and specificially, to assess which $T$ pallidum antigens were recognised by serum from infected mice at various times after inoculation. The western blotting procedure was used to identify $T$ pallidum and $T$ phagedenis biotype Reiter antigens that reacted with serum from infected mice. $T$ pallidum and $T$ phagedenis biotype Reiter proteins were separated by SDS-PAGE and, although each gave a complex gel electrophoresis profile (fig 1), similarities with and appreciable differences between the polypeptide profiles of these organisms and the profile obtained on electrophoresis of normal testicular extract can be seen.

The number of $T$ pallidum antigens recognised by serum from infected mice increased gradually during 126 days after inoculation (fig 2 ) and then remained constant until 180 days after infection. These results correlate interestingly with the ELISA and MHA-TP assays described previously in this laboratory, ${ }^{4}$ which showed a quantitative increase in antibody directed against $T$ pallidum for 84 days after inoculation, with antibody concentrations dropping slightly thereafter but remaining appreciable. Thus mice infected with $T$ pallidum develop antibodies against the organism and the response increases quantitatively until about 84 days after infection, yet the humoral immune response continues to develop qualitatively for 126 days after infection as the mice continue to develop antibodies that recognise additional $T$ pallidum antigens during that time. When rabbits are infected intratesticularly with $T$ pallidum they develop antibodies capable of recognising $T$ pallidum antigens by western blotting as early as three days after inoculation, and essentially the full complement of $T$ pallidum antigens that rabbit serum appears to be able to recognise are detected by day 21 after infection with the organism. ${ }^{15} 16$ Serum from people with secondary syphilis recognises a similarly complex $T$ pallidum antigen profile. ${ }^{12}$ At that stage of the illness, the organisms may have persisted in the lymphoid system for several months. In our study, the mice infected with $T$ pallidum developed a complex humoral immune response to $T$ pallidum antigens, allbeit at an appreciably slower rate than rabbits. This may have been due to the poor immunogenicity of $T$ pallidum in experimentally infected mice as suggested by these and previous studies. ${ }^{4,5,17,18}$ Figure 3 shows that serum from mice or rabbits infected with $T$ pallidum as well as from people with secondary syphilis is able to recognise most of the same $T$ pallidum or $T$ phagedenis biotype Reiter antigens, as shown by the similar antigenic profiles. Several $T$ pallidum antigens appeared characteristically to be recognised by the serum of mice, rabbits, or people infected with $T$ pallidum. These included two low molecular weight antigens (about 12000 and 14000 daltons) as well as several major antigens of medium molecular weight (about 42000 to 48000 daltons).

Serum from inbred mice infected with $T$ pallidum also detected up to five $T$ phagedenis biotype Reiter antigens. This confirms the results obtained in rabbits, whose serum also reacted with five to eight antigens, and probably represents cross reactive antigens between $T$ pallidum and $T$ phagedenis biotype Reiter as detected by the western blot technique (fig 3). ${ }^{12} 16$ We found that serum obtained from people with secondary syphilis also reacted with six to eight $T$ phagedenis biotype Reiter antigens (fig 3). ${ }^{12}$ Other workers using a crossed immunoelectrophoresis procedure showed that serum from patients with secondary syphilis recognised up to five cross reactive antigens. ${ }^{19}$

Mice infected with heat killed $T$ pallidum failed to develop an appreciable antibody response against $T$ pallidum. This suggests that viable organisms are required to establish a persistent infection for mice to mount an appreciable antibody response to $T$ pallidum. The need for viable organisms correlated well with several attempts by other workers to immunise rabbits against infection with $T$ pallidum. ${ }^{2021}$ Viable organisms were generally needed to obtain protective immunity, although two instances of partial protection afforded by inactivated $T$ pallidum have been reported. ${ }^{22} 23$

Mice inoculated with $T$ pallidum were subsequently treated with antibiotics to interrupt persistence of the organism and to assess the effect on the antibody response to $T$ pallidum antigens. Serum from mice receiving penicillin from day 2 after infection (group 3 , fig 4) recognised a similar set of $T$ pallidum antigens until day 42 as those recognised by serum from the mice that did not receive antibiotics (group 1, fig 2). Mice from group 3, however, failed to develop antibodies to additional $T$ pallidum antigens, 
and by day 84 fewer antigens were detected. Mice receiving tetracycline from day 2 after infection (group 4) developed antibody to only the two antigens that were normally detected early in infection. Mice receiving either penicillin or tetracycline from $\mathbf{4 2}$ days after inoculation (groups 5 and 6, fig 5) began to develop an antibody response that could be interrupted once antibiotic treatment was begun. Assuming that the antibiotics effectively erradicate $T$ pallidum, these experiments support the concept that the organisms must persist for a long period of time for mice to develop a complete response to $T$ pallidum antigens. As rabbits are known to become immune a few months after inoculation with $T$ pallidum, ${ }^{20}{ }^{21}$ and as treatment with antibiotics can block the development of immunity, it would be interesting to monitor rabbits, some of which are given antibiotics, to assess which antigens are recognised.

The results presented here confirm and extend our previous work regarding the development of the humoral immune response of mice to $T$ pallidum. The immunoblot technique confirmed the slow response of mice to $T$ pallidum antigens and also indicated which antigens are recognised. Interestingly, serum from mice recognises some of the same $T$ pallidum and $T$ phagedenis biotype Reiter antigens as are recognised by serum from rabbits infected with $T$ pallidum or from people with secondary syphilis. This is an important consideration as mouse splenocytes are generally used to construct hybridomas, and monoclonal antibodies that will recognise clinically important antigens would certainly be required. help.

We thank Ms Renee W Martin for her expert secretarial

\section{References}

1. Centers for Disease Control. Syphilis trends in the United States. MMWR 1981;30:441-5.

2. Magnuson HJ, Thomas EW, Olansky S, Kaplan BI, DeMello L Culter JC. Inoculation of syphilis in human volunteers. Medicine 1956; 34:33-82.

3. Magnuson HJ, Rosenau BJ, Clark JW Jr. The rate of development and degree of acquired immunity in experimental syphilis. American Journal of Syphilis, Gonorrhoea and Venereal Diseases 1948; 32:418-26.
4. Folds JD, Rauchbach AS, Shores E, Saunders JM. Evaluation of the inbred mouse as a model for experimental Treponema pallidum infection. Scand J Immunol 1983; 18:201-6.

5. Gueft B, Rosahn PD. Experimental mouse syphilis, a critical review of the literature. American Journal of Syphilis, Gonorrhea and Venereal Diseases 1948;21:59-88.

6. Pavia CS, Folds JD, Baseman JB. Depression of lymphocyte response to concanavalin $\mathrm{A}$ in rabbits infected with Treponema pallidum (Nichols strain). Infect Immun 1976; 14:320-2.

7. Hanff $\mathbf{P}$, Norris S, Lovett M, Miller J. Purification of Treponema pallidum, Nichols strain, by Percoll density gradient centrifugation. Sex Transm Dis 1984;11:275-86.

8. Stout GW, Kellogg DS Jr, Falcone VH, McGrew BE, Lewis JS. Preparation and standardization of the sorbent used in the fluorescent treponemal antibody-absorption (FTA-ABS) test. Public Health Lab Sci 1967; 4:5-8.

9. Latt RH. Drug dosages for laboratory animals. In: Melby EC Jr, Allman NH, eds. CRC Handbook of laboratory animal science. Vol III. Boca Raton, Florida, USA: CRC Press, 1976.

10. Laemmli UK. Cleavage of structural proteins during the assembly of the head of bacteriophage T4. Nature 1970; 227:680-5.

11. Towbin H, Staerelin T, Gordon J. Electrophoretic transfer of proteins from polyacrylamide gels to nitrocullulose sheets: procedure and some applications. Proc Natl Acad Sci USA 1976; 76:4350-4.

12. Hanff PA, Fehninger TE, Miller JN, Lovett MA. Humoral immune response in human syphillis to polypeptides of Treponema pallidum. J Immunol 1982; 129: 1287-91.

13. Klein J, Monjan AA, Hardy PH, Cole GA. Abrogation of genetically controlled resistance of mice to $T$ pallidum by irradiation. Nature 1980; 283:572-4.

14. Wright DJM, Gaugas JM, Rees RJW. T pallidum in mice with suppressed cell mediated immunity. Guy's Hospital Reports 1975; 123:385-90.

15. Hanff PA, Bishop NH, Miller JN, Lovett MA. Humoral immune response in human syphilis to polypeptides of Treponema pallidum. J Immunol 1983; 131: 1973-7.

16. Lukehart SA, Baker-Zander SA, Gubish ER Jr. Identification of Treponema pallidum antigens: comparison with a nonpathogenic treponeme. J. Immunol 1982; 129:833-8.

17. Ohta Y. Treponema pallidum antibodies in syphilitic mice as determined by immunofluorescence and passive hemagglutination techniques. J Immunol 1972; 108:921-6.

18. Schell RF, Musher DM, Jacobson K, Schwethelem P. New evidence for the non-infectivity of $T$ pallidum for mice. British Journal of Venereal Diseases 1975;51:19-21.

19. Pedersen NS, Axelsen NH, Jorgensen BB, Petersen CS. Antibodies in secondary syphillis against five of forty Reiter treponeme antigens. Scand J Immunol 1980;11:629-33.

20. Miller J. Potential for vaccines for venereal diseases. Bull NY Acad Med 1976;52:986-99.

21. Musher D, Baughn R, Lapushin R, Knox J, Duncan WC. The role of a vaccine for syphilis. Sex Transm Dis 1977;4:163-8.

22. Metzer $\mathbf{M}$, Smogor $\mathbf{W}$. Artificial immunization of rabbits against syphilis. I. Effect of increasing doses of treponemes given by the intramuscular route. British Journal of Venereal Diseases 1969;45:308-12.

23. Miller JN. Immunity in experimental syphilis. VI. Successful vaccination of rabbits with Treponema pallidum. Nichols strain, attenuated by irradiation. J Imınunol 1973;110: 1206-15. 